\title{
Soft Tissue Sarcoma of the Abdomen and Thoracic Visceral Organs Pathologic Distant Metastasis TNM Finding v8
}

National Cancer Institute

\section{Source}

National Cancer Institute. Soft Tissue Sarcoma of the Abdomen and Thoracic Visceral

Organs Pathologic Distant Metastasis TNM Finding v8. NCI Thesaurus. Code C136730.

A pathologic finding about one or more characteristics of soft tissue sarcoma of the abdomen and thoracic visceral organs, following the rules of the TNM AJCC v8 classification system as they pertain to distant metastases. 